\title{
The law pertaining to food issues and natural resources exploitation and trade
}

\author{
François Collart Dutilleul
}

\begin{abstract}
Background: The questions of the access to natural resources, their use, repartition or commercialization concern both the areas of food safety, protection of the environment and economic development. But whether we look at what the land offers or produces, the repartition of natural resources around the world coincide neither with the map of food needs nor the map of development. This is bitterly obvious in light of the latest failures, or at least partial failures, of the three main international negotiations: the FAO Summit on food safety, the WTO Doha Round on international agricultural trade and the negotiations of the Intergovernmental Panel on climate change (IPCC). In fact, these three negotiations, which are part of a global strategy of sustainable development, will only succeed if we not only take into account the economic, scientific and political aspects but also try to comprehend the judicial causes of the problems.

Results: We wish to determine the appropriate way to determine a law on natural resources that preserves on every continent the food safety. This safety supposes that the agricultural and feeding purposes of the land be maintained, that farmers and their families can access the land and live decently from it and that access to healthy food in sufficient supplying be guaranteed to everyone.

Conclusion: None of the objectives will be achieved without the law conveying the values that society will choose for itself. Between the law and the contract, collective security and individual freedom or between State sovereignty and globalization of trade, one must think of a humanist law to help the Earth to feed Humanity.
\end{abstract}

\section{Introduction}

The link between natural resources and food is too obvious to have to be proven right. Every one of us can experience it in everything we eat that comes from the earth's resources. It follows that food issues concerning trade in natural resources also seem obvious. What is not obvious, however, is the way the connection may be made between the various forms of natural resources exploitation and trade on the one hand and the worldwide consequences in terms of food supplies on the other hand.

Needless to say it partly depends on the way the scope of natural resources is defined. According to the WTO, natural resources consist of 'the material stores that can be found in their natural environment which are both rare and economically useful either in the raw state or after a minimal transformation' [1]. The scope is thus limited and mainly covers fishing and forestry products, fuels, ores, and other ferrous or non-ferrous minerals.

Correspondence: francois.collart-dutilleul@univ-nantes.fr

MSH Ange Guépin, 5 allée Jacques Berque, Nantes cedex 1, 44021, France
We would prefer to consider a broader meaning which is legally more useful regarding food issues, including land itself, agricultural raw materials, water, and biodiversity resources. The criterion of inclusion is more a political than an economic one. The definition comprises land and the resources taken from the natural environment by extraction, capture, or culture which can be traded and have a significant impact on the planet or its peoples, justifying the implementation of public policies of protection, management, and import quotas.

Indeed, the most important point is to know how natural resources exploitation and trade should be organized and thus managed for food security to be optimal on all continents.

The response is partly ideological, dogmatic, or religious. But it is partly also strictly political. More often than not, the advocates of such-and-such a policy dress up their choices in a pseudo-legal form to make it more convincing and logical. When dealing with natural resources exploitation and trade, the laws of economics, 
the market, nature, science, ethics, or indeed God (depending on one's secular or religious inspiration) are commonly referred to.

For this reason there is much debate to know whether, in order to feed those who starve and ultimately to feed the world, international trade and free trade in agricultural raw materials have to be furthered; whether technical, biological, and chemical innovations should be developed by promoting nanotechnologies or productive farming methods; or whether human and social values should prevail by referring to ethics, morals, religion, cultural and historical diversity, and by encouraging operators and consumers alike to reconsider their habits and criteria by themselves. Should economics, science, or ethics be trusted for the natural resources to meet our basic food needs?

Economic liberalism has enabled a great increase in the generation of wealth, but it has not shown an ability to reduce hunger, poverty, and under-development while preserving our resources. The scientific and technical breakthroughs which have revolutionized agriculture, food, and health have undeniably allowed us to improve overall worldwide food security, but at the cost of degrading our environment and resources as well as opening up a wide gap between the rich North and the poorer South. Should we then turn to ethics? Will promoting ethical consumption and production be enough on its own to neutralize the addiction to wealth shown in Stupid Cupid's behavior ${ }^{\mathrm{a}}$ and the vagaries of history, geography, and climate?

In fact, all of human experience shows that thinking globally about the exploitation and trade of resources, particularly natural resources, without a framework of law comes down to accepting the law of the strongest, whether the strength be economic, scientific, moral, or religious.

What is missing in the admittedly truly real assets contributed by economics, science, or ethics is the force of law whose first function is, to use Kant's famous distinction, to build on the difference between what has a price and what has dignity ${ }^{\mathrm{b}}$ and to draw conclusions in terms of social rules. But that is not enough, precisely because some commodities with a price are essential to the respect of people's dignity. Such is the case of commodities enabling people's vital needs to be met - first among them natural resources, made up of land and its output. That is why the missing element is a law whose goal is the respect of people's dignity, starting with the respect of their right to live, and therefore with food security [2].

Thus determining the role of Law regarding food issues and natural resources exploitation and trade is to step in a direction that will pave the way for the respect of life and dignity. Yet questions concerning food cannot be set apart from those concerning freedom either. As Jeanne Hersch aptly put it, 'what is required by the declaration (universal declaration of Human Rights) is that the urge for vital needs (food, housing, etc.) be tempered for humans and their closest fellows so as to increase opportunities for freedom' [3]. Approximately 17,000 or 18,000 years ago, human beings painted beautiful frescoes on the walls of the Lascaux caves, bearing witness to a dramatic cultural development on which freedom had been gradually built. They would never have been able to achieve that much if they had had to spend most of their time nomadically hunting and gathering, day after day, to feed themselves and their families.

The Lascaux frescoes thus resulted from a basic social organization and task-sharing, permanent settlement on a territory and finding ways to share available resources and feed those who lived there. Lascaux encapsulates the origins of the three elements which enabled a social group to develop a common culture on which to found a society and achieve freedom: Law-Food-Land [4].

But how can we conceive and draft the body of law that is needed for the Earth and what it possesses and produces to be able to serve everyone's development, and first of all the goal of food security?

To write this law, it is certainly necessary to start with a diagnosis of the forces that are currently acting - mainly market forces - in order to identify the levers the forthcoming law should act on. Once the acting forces have been identified, it becomes possible to summon up the 'imagining forces of law' according to Mireille DelmasMarty's well-found expression ${ }^{\mathrm{c}}$. This presupposes determining the values on which the law must be conceived in order for humankind to be a reality and not merely a concept and, consequently, to sort out what should be determined by price from what should be governed by dignity.

\section{Acting market forces}

To identify the acting forces, we will rely on Karl Polanyi's thesis that he developed in his master work The Great Transformation [5]. This choice is justified first because the economic model that emerges includes the food issues resulting from the development of a free trade economy leading to a global self-regulating market. It is also justified by the explanatory relevance of the market model throughout modern history, both in cases of attempts to control the market and in times of crisis. However, we will try to consider this model in an empirical way, with an inductive method adapted from Francis Bacon's Novum organum [6]. It has indeed to be remembered that there is no way to scientifically establish if the easing of restrictions on trade is the source of the problem or, conversely, if it must be furthered to lead to a solution. Pure logic does not enable us to state whether speculation is or is not the cause of price volatility and food crises. There is no overall 
agreement on the benefits and detriments of nanotechnologies to nature and people. In the face of the many controversies - often colored by ideology - the analysis rather requires an empirical, inductive method like that of Bacon's 'Four Idols' doctrine and tables to identify the various sources of error and to compare the cases in which an observed phenomenon does or does not recur. To a legal professional - even though law is not a science - this 'New Tool' offered by Bacon is interesting since it is an alternative to the mainstream syllogism inherited from Aristotle's Organon.

\section{The great transformation}

The question of food issues in natural resources exploitation and trade is deeply rooted in a broader conception of a global self-regulating market that the economist Karl Polanyi studied in depth in his master work The Great Transformation.

In his work, Polanyi built his thesis [7] particularly on the history of 18th- and 19th-century England, a time and place where, according to the author, the reality of such a global self-regulating market was born. It is indeed very enlightening to step back two or three centuries and observe how the three commodities consisting of land and the natural resources it holds or produces, money and the financial resources it provides, and labor and the related human resources, enabled the development of the idea and the reality of such a market, on which we have continued to rely for our living until today. Indeed, for Karl Polanyi, free trade is built upon two pillars.

The first one is the autonomy of the economy with regard to politics. If the economy is subordinated to politics, the market is politically oriented thus legally restricted and as a consequence it cannot self-regulate. So, self-regulation implies an easing of restrictions on trade and a political, legal withdrawal. Besides, it can be seen that in various times and especially in our own, the very right of existence of 'international political economy' as a discipline has been contested [8]. One can also notice how today's economic policies aim at buffering the impact of free trade rather than restricting the play of the free market.

This autonomy of the economy with regard to politics (and thus law) supports the idea developed by Michel Foucault in his analysis of economic liberalism [9] stating that legal and economic goals cannot be pursued at the same time. For Michel Foucault, indeed, homo oeconomicus is capable of pursuing his personal interest in an unlimited way. There is no limit to the wealth a person can try and accumulate. One's personal economic interest is certainly not restricted by that of other people. The best, the cleverest, or the luckiest can thus become rich at the expense of others, without having to answer for their actions legally. But, from a legal point of view, each person's interest is restricted by the others' and by the general interest. Nobody can live his personal, family, or social life without taking others' lives into account, or to the detriment of others, unless he is held responsible; thus the law-economy antinomy and the difficulty in designing legal restrictions for a free trade economy.

The second pillar of the great self-regulating market, according to Polanyi, consists of three imaginary commodities: land, money, and labour. These commodities are imaginary since they do not satisfy 'the postulate according to which everything that is bought and sold must have been produced to be sold' [10]. This postulate could well be one of Bacon's 'idols'. Neither labor (human beings' vital force) nor land (nature) nor money (representing purchasing power) is 'produced' to be sold. But they are all at the heart of the economic machinery enabling all trade in goods and services. Indeed, these three imaginary commodities have to be subjected to the market themselves for the economic system - via the organization of the production and distribution of goods and services - to be self-regulated. According to Polanyi, 'humans are expected to behave in such a way as to earn as much money as possible: such is the origin of this kind of economy. It assumes there are markets on which the availability of commodities (including services) at a given price matches demand at the same price (...). Consequently, there are markets for each and every element of industry, not only for goods (including services), but also for labor, land, and money, their prices being respectively called foodstuff prices, wages, land revenue or "rent" and interest' [11]. In this analysis, the self-regulating 'Great Single Market' Polanyi describes was able to develop when land (together with what it holds and produces), money, and labor were themselves subjected to self-regulating markets.

As far as natural resources are concerned, the author demonstrates the birth of a market for land starting with the 'enclosures' movement [12]. This movement, which had already begun in the 13th century, consisted in turning the 'Commons' - the lands which were shared by a community's farmers - into private plots which were regrouped then 'enclosed' and attributed. The phenomenon is partly due to the need to rationalize plots in order to increase yields. In the 18th century, it also aimed to boost breeding to provide the emerging English textile industry with wool. The development of enclosures thus produced wealth linked to the increase in farming production and productivity. But at the same time it led to the expropriation of a whole class of farmers. Some of them would be employed by the new landowners, contributing to the development of farming in enclosures. The others would be expropriated, left on their own without a living, and they would leave the countryside to 
increase the population of the cities, a phenomenon at the origin of almost all megalopolises, particularly in the developing world. In England, riots slowed the enclosures movement. But enclosures, over the decades, would eventually spread, forced upon the rural economy by hundreds of specific laws passed from 1750 onwards [13]. The enclosures movement thus transformed land and natural resources into goods.

This 'great transformation' had devastating effects, only slightly mitigated by laws introducing a measure of charity for the poor ${ }^{\text {. }}$.

Legally, the market won the day, with a change from a legal system based on common goods to one based on the private ownership of land, together with charitable laws to maintain social peace in spite of the increase in poverty.

Economic development ${ }^{\mathrm{e}}$ was thus acquired at a dramatic social cost, so that 'what has a price' clearly won over 'what has dignity'.

\section{Attempts to control the market}

Market controls lead to intermediate stages between a fully liberal economy and a fully regulated one.

In their strictest form, these controls can consist in regulating prices to avoid excessive increases - which generate food crises - or too high volatility. In this case, the market no longer self-regulates, it is quite simply neutralized. There was such an attempt in France after Turgot's edict which eased regulation in the grain trade, particularly for the price of wheat, at least until a late stage of the French Revolution [14]. There was at that time a very enlightening series of changes back and forth between imposing and then easing controls on prices. Yet each period of easing triggered a rise in prices, engendering riots which were dealt with by martial law. Conversely, each period of controls was accompanied by the end of martial law. This movement between free prices (during times of easing of restrictions) and free people (during times of price control) provoked over the whole period a social debate between the advocates of free trade and their opponents, a debate whose economic terms can still be used almost word for word today [15] In particular it focused on the fact that grain (or farming products as a whole) is not like any other commodity, being renewable, vital, and so on, and also on the part played by middlemen and speculators.

It is a recurrent debate, and it was particularly relevant, politically speaking, in the 1940s when the Allies, while still at war, sought to set up the bases of a new, prosperous, peaceful world. Initiated by President Roosevelt who wanted to establish the basis of a new worldwide organization for a sustainable post-war peace, 10 or so international conferences met successively in the Allied countries [16]. Among them, those hosted in Hot Springs in May 1943, Philadelphia in May 1944, and Bretton Woods in July 1944 are particularly relevant here.

The Hot Springs conference was set up with the idea that the eradication of starvation and poverty was a criterion for peace. This conference had two major effects. For the first time, it bound together natural resources, farming, and food in the public policies to be implemented at national and international levels. It also gave birth to an international organization that would become the FAO 2 years later. The final Act of Hot Springs referred to food as a right of humankind. The setting up of a policy of plenty was favored, and thus the development of the exploitation of agricultural resources and increased productivity of food resources. International trade in foodstuffs and international cooperation to eradicate starvation were encouraged. States were asked to commit to taking all necessary measures to secure their populations' food security. The specific needs of fragile populations were also noted. Fair prices for farmers were favored. The necessity for states to directly intervene 'from spade to spoon' as one might say now was recognized. The goal was set to limit the fluctuation of the prices of food and farming products. Basically, Hot Springs favored a kind of economic interventionism in the exploitation, management, and trade of food-linked natural resources. This is a long way from thinking of foods as conventional commodities, even further from instituting a self-regulating market. Much closer indeed to numerous NGOs' demands today. But everybody has forgotten Hot Springs, only to remember Bretton Woods.

Nonetheless, the conclusions of the Bretton Woods conference were partly along the same lines since, while promoting international trade, particularly with a set of arrangements later formalized as GATT, it set up an international monetary system which, being organized around the U.S. dollar but tied to gold, shielded currencies from pure market regulation. Bretton Woods also created the international bank and the International Monetary Fund (IMF).

As for the Philadelphia conference which reorganized the International Labor Organization, it started by postulating, among other key principles, that labor is not a commodity.

It can thus be assumed the international community has learnt from history and 'what has dignity' is at least as valuable as 'what has a price'. After these conferences, the economy would lose its autonomy and be subordinated to politics. Secondly and above all, land and the food resources it holds and produces (Hot Springs), labor (Philadelphia), and money (Bretton Woods) would no longer be considered as conventional commodities subjected to self-regulating markets.

But as everybody knows and has noted, the spirit of Philadelphia, to quote the phrase (and analysis) of one 
author, has given way to the global market [17]. The determination witnessed at Hot Springs has not been strong enough to prevent the trade in food natural resources from being governed by GATT rather than the FAO. The intelligence shown at Bretton Woods was not able to prevent the damage done to the international monetary system in the 1970s. The self-regulating market reasserted itself in its unrestricted, ultra-liberal form which Hayek calls 'the spontaneous market order' [18] and which could well be one of the 'idols' that the method Bacon favoued should enable us to identify.

\section{The crises of the self-regulating market}

The pendulum has now swung back, so that a selfregulating market is now clearly seen as 'a crazy idea' [19] One can well remember the sub-primes crisis in the second semester of 2006, which broke on the world in February 2007. One can also remember the first financial crisis which resulted, in summer 2007, and reached a climax in the fall of 2008 when the first effects of the economic recession and unemployment started to be felt worldwide.

On the other hand, several factors have been paving the way for the risk of a food crisis scenario since 2005-2006: the destruction of arable lands through population drain or urban development, the overuse of inputs, climate change, the rise in demand for food, the oil price rise, the increase in bio-fuel crops, and so on. Foodstuff prices are both volatile and bound to increase in the long run. This is the scenario in which the sub-primes crisis and the resulting financial crisis were set. On the one hand, central banks poured hundreds of billions of liquidities into banks which invested in blue-chip stock like agricultural raw materials. On the other hand the hedge funds, torn to pieces by the financial crisis, tried to make up their losses on the agricultural raw materials settlement market. It all led to a huge speculation which unsettled the already fragile prices of agricultural raw materials. This is why from February 2007 onwards, when the sub-primes crises became public and the financial catastrophe began, foodstuff prices rocketed to reach a peak in February 2008, provoking a food crisis in a number of countries ${ }^{f}$.

This recent history of crises can help us to understand the phenomena that the issue of food is linked to. Indeed, the sub-prime crisis is related to land-commodity (and to that other basic need, housing); the financial crisis is related to money-commodity; the economic crisis triggering unemployment is related to labor-commodity. It shows that behind the crises the world has experienced, which has sent the least developed countries into a food crisis, there are in fact, in Polanyi's terms, three commodities in crisis: land and its uses, money, and labor.

It is truly a crisis of resources that the world has had to face: the degradation of natural, financial, and human resources. And land and natural resources are in deep crisis. This has become dramatically evident, especially since the end of 2009.

In late 2009, the future of natural resources was decided in three international conferences directly or indirectly dealing with food natural resources: the WTO negotiations on agricultural products trade in Geneva in December, FAO's on food security in Rome in November, and the conference on global warming in Copenhagen in December. Yet, these three meetings failed and in none of these areas has there been any successful outcome so far. What can be learnt from this?

Indeed, these three negotiations recall the main issue of the Hot Springs conference in 1943. They addressed the question of the link between the trade in natural resources and food issues. But the Hot Springs declaration did not provided for any sanctions or other constraints. And the 2009 negotiations did not succeed in forcing anything upon states. Given this, should we not appeal to the imagining forces of law?

\section{The 'imagining forces of law'}

To write law, vocabulary and grammar are needed. The vocabulary designates concepts conveying the values we choose to promote and the grammar is the way to connect these concepts to one another, whether they be 'economic liberty', 'political liberty', 'people's dignity', 'individual responsibility, 'sustainable development, 'food security, 'private property', sovereignty, or common goods. To apprehend this vocabulary and grammar, we would prefer to speak in terms of 'law' (or rules) rather than 'regulation' or 'controls', in order to avoid the confusion often made (and which have resulted in the worship of some of Bacon's 'idols'). So let us assume that 'law' differs from 'controls' in the same way as the Highway Code differs from ways to keep the traffic flowing. Prices or speculation can be 'controlled' the way temperature is, that is by setting limits, upper and lower. Controls aim to steady or balance a complex system. Though necessary, they are far from being enough. Law (like 'controls') sets behavioral principles and rules. Through law, social values will be promoted to guide the economy the way society wants it to be, somewhere between maximizing profits and giving priority to people's dignity.

\section{Setting the goal of food security}

International law currently governing natural resources exploitation and trade does not aim at securing food security worldwide. Its goals are economic and it relies on two principles: the sovereignty of States over their natural resources and free international trade [20]. The laws currently in force partly match the WTO's, without any specificity regarding agricultural natural resources, subject to the successful outcome of the Doha Round of negotiations ${ }^{\mathrm{g}}$. The laws are also partly the result of international 
agreements and treaties, as well as an increasing number of bilateral treaties [21]. Concerning food resources, it is the organization of fishing and the sharing of halieutic resources that are mainly concerned, precisely because when dealing with the seas and oceans, the allocation of fishing grounds cannot be achieved simply by applying the principle of State sovereignty. Basically, international market law is sufficient when applied to what has a price but not to what has dignity, to quote Kant once more.

We should not hesitate to qualify food security as a priority and a non-negotiable goal. This is justified simply if starving to death is to be outlawed and if it is a condition for world peace, as it was at the Hot Springs conference in 1943. It has been at the core of the language of the FAO ever since, but it has not broken through as law. FAO defined this priority in the worldwide summit on food in 1996: 'Food security is provided when all people, at all times, can economically, socially and physically have access to enough safe, nutritive food to satisfy their nutritional needs and food preferences to enable them to live an active, healthy life' [22].

On the other hand, food security also consists in preventing food crises. In this respect, the billion or so people who do not have sufficient access to adequate food should be seen as the victims of a permanent food crisis. Given this, food security should appear in two forms. One of these would be devoted to all such victims, just as social protection is organized in the form of 'social security'. The other one should consist in designing laws governing the production and trade of food agricultural raw materials that take into account the need to feed 9 billion people by 2050 .

Thus conceived, the goal of food security has direct repercussions on the legal treatment of natural resources. Land is a limited, non-extensible commodity. What it produces, though renewable, can become exhausted. Fisheries are the same. So are forests and water. Limited and exhaustible natural resources should be considered as a patrimony or capital and not as goods, especially not as conventional ones. More precisely, their exploitation and trade should be governed by public policies varying from state to state, recognized by international law, thus removing them from sheer market forces. These rules should take into account the fact that the vital character of these food resources gives them a general interest and common dimension at the outset.

\section{Defining a sustainable development strategy}

The Geneva, Rome, and Copenhagen negotiations that took place in late 2009 linked together the destinies of an economic issue - the development of international trade and commerce, an environmental issue - global warming, and a social issue - poverty and its links with famine, malnutrition, and food crises. Now these three issues precisely match the three pillars of sustainable development: economic dynamism, environmental care and social progress: Profit, Planet, People.

It will not be a surprise to find here the three imaginary commodities whose history has been highlighted by Polanyi: money as a way to measure profits, land as an issue in protecting the planet and labor as a means for people to secure an income and thus food for themselves and their families. While the global self-regulating market consists in merchandising land, money, and labor, global sustainable development for its part relies on considering the economic, environmental, and social dimensions as indissociable. This means each political action or decision should take into account the three dimensions together, and should be responsible for the consequences of doing so.

Yet history shows that such an 'indissociation' cannot result from a great self-regulating market. Sustainability of development cannot result from a purely economic, scientific, or ethical approach. It can only result from a politically expressed, legally organized will [23].

However, the goal of legislation should not be to put an end to either the great market or free trade. In the wake of Max Weber's doctrine, it is obvious that there is not one single legal system suited to free trade [24]. We simply have to abandon the 'idols' of self-regulation and deregulation which have prevailed in almost all economic sectors since the 1970s. The problem with the three post-war conferences (Hot Springs, Bretton Woods, and Philadelphia) is that they were dissociated from one another. The same problem occurred in November and December 2009 with the separate Rome, Geneva, and Copenhagen negotiations - they eventually failed. This was inevitable: it makes no sense to restrain the unbridled exploitation of natural resources in Copenhagen if their free trade is promoted in Geneva at the same time. And such promotion itself is pointless if we are to work towards the goal of food security in the long run. Food security has no future if what is discussed separately in Rome is neglected in Copenhagen.

To reach its objectives, the law we have to imagine must forge links between economic laws and dynamic trade, the laws of science and technical progress, moral laws, and human values.

Therefore our first problem is the current segmentation of institutions, conferences, negotiations, policies, and decisions. The great market model can only work if it reaches a balance between supply and demand for all goods and services. To do so, we should let the forces of supply and demand act for land and its resources, for money, and for labor. But, with the constant interplay of the various markets and the successive crises, history has shown that this is ineffective. The homo oeconomicus is only rational to a certain extent and on condition he has enough food and a safe environment to live in. This is the 
'indissociation' that the sustainable development concept allows us to implement. Given this, in these conditions and within the framework established by the United Nations General Assembly [25], what legal resources or instruments could restore 'what has dignity' to its rightful status?

\section{Structuring the legal resources to be implemented}

There is a fairly wide range of legal resources available to enable us to come as close as possible to the goal of food security while implementing a sustainable development strategy.

To define them and choose among them, it must first be stated that a sustainable development strategy provides us with at least three categories of values that have been shared by the international community since the Rio declaration of 1992. They constitute a strong basis which avoids immediately confronting the question of the universalism or relativism of values [26]. The legal resources we decide upon and structure should then enable economic dynamism, health and environmental care, and social progress to be achieved. Besides, the instruments we design must be based on legal concepts capable of 'sounding the conscience' [27] as well as appealing to reason.

Up to now, freedom has been favored: free access to resources, free exploitation, free trade, and consequently freedom to do business, contractual freedom, free competition, free movement of goods, capital, and people ${ }^{\mathrm{h}}$. Some say failures, poverty, and famine can be explained by restrictions to this freedom ${ }^{\mathrm{i}}$. Others, however, think that free trade in natural resources accounts for the problem and the food crises. The main point surely is to lend a legal, constraining form to the limits on freedom, particularly by exploring means of maintaining public policy which that legal form or instrument should target. We can thus try to design an internationally-dimensioned concept of 'food public policy' (or food 'ordre public'), on the model of the WTO's TRIPS agreement for patents'. Regarding the freedom of imports and exports, of economic price-setting mechanisms, of speculation on commodities, an 'order' has to be imagined and made 'public'. Economic liberties and legal responsibility also have to be concretely and conceptually re-associated, these values having been largely dissociated since the series of world crises that started in 2005-2006.

Another resource, which has been extensively tried and tested, is basic rights. There are already a considerable number of texts which lay them down but they pose the problem of a lack of efficiency in terms of positive law. Things tend to be different, relatively speaking, when a judge or a court is instituted in parallel to enforce the rights which have been laid down ${ }^{\mathrm{k}}$. The basic rights resource is nevertheless very symptomatic of the vital need to ensure each individual's food security. That is why it is promoted by the UN's special rapporteur on food rights to fight the excesses of free trade. ${ }^{1}$. But an effective legal system remains to be defined to defend farmers' access to land and people's access to food [28].

A legal framework for the market can also be imagined based on the concept of 'sovereignty' in the form of both access to land (land sovereignty) and access to food (food sovereignty).

Land sovereignty determines the means States can use to keep natural resources, particularly agricultural lands, under control, particularly seeking to prevent their capture by public or foreign powers. This form of sovereignty is a reaction to a new kind of colonization consisting of foreign states or companies buying up developing countries' productive lands. FAO has made proposals supporting the idea [29]. However, these proposals need to be clarified, particularly by designing model contracts preserving the rights of local populations and the interests of host states [30]. The food security of the countries involved requires all lands to be available to populations living on the states' territories. The corollary of this State land sovereignty is the obligation on these states to provide their inhabitants with the means of subsistence. Besides, experience shows that grabbing these lands is often an opaque process, which mainly benefits the capturing investor: a minimal price is paid for the land, legally or not, before or after taking it, and it is at best unclear who the final payee is. Furthermore, the investor's commitments regarding local employment, the species of crops to grow and the destination of the produce are often vague. Eventually, once the contract comes to an end, the investor often leaves a land which has been impoverished by overexploitation without being environmentally restored.

Food sovereignty, on the other hand, determines a state's ability to define public policies designed to provide the population with enough healthy food. This is the means favored by Via Campesina [31] which has developed a thorough, demanding food sovereignty concept which extends to a full set of public policies to be implemented to provide the population with food: farmers' access to land, water, seeds, and loans; priority given to local produce to feed the population; the right of farmers and consumers to choose the methods of production and the products consumed; the right of states to protect themselves from low-cost imports by banning or taxing them; populations having their say in political decisions concerning agriculture; protection of women's rights, and so on. In addition to these proposals, which merit thorough debate, it is at least necessary to define the legal tools necessary for the implementation of an agricultural protectionism limiting the power of the WTO and the globalization of trade. In this respect, the concept of food autonomy, compatible with maintaining a system of multilateral trade, would enable states to keep a 
measure of legal discretion to adapt their agricultural and food policies to their own particular needs. So in the context of sovereignty and autonomy, there is a means to legally regulate exploitation and trade in food natural resources while avoiding excesses. However, a population cannot be confined within a country's borders without the necessary food. Consequently, a state cannot be deprived of the right to make the necessary decisions to feed its population, and both national and international laws should take this into account.

In compatibility with the concepts of sovereignty and autonomy, ownership and the qualification of 'common goods' should be explored as ways to access resources. Several definitions of common goods have been proposed in a thriving, mainly economic, literature [32]. Yet the concept is often assimilated simplistically, as Garett Hardin has done [33], to merely being in competition with private property [34]. In reality, deforestation, excessive inputs, wastage of water, or overexploitation of resources can occur under conditions of common goods as well as private ownership. Ownership can be private or public, individual or collective, absolute or relative, without competition or open to coexisting uses. It is therefore possible to optimize a right to ownership which regulates the owners' power in favor of the common, and others', interests [35], a right which defines a way to manage ownership that respects the specificity and scarcity of the natural resources concerned ${ }^{\mathrm{m}}$, or even a right that bestows a social function on ownership [36]. Much in the same way, the management of common goods can be legally organized to guarantee a chosen yield, by preserving the quality and quantity of resources. The main point is the values which are promoted rather than the legal means used.

The choice between ownership and common goods also has to be made when turning our attention to incorporeal goods in the field of 'intellectual property'. Patents on living organisms, biodiversity or natural resources [37], plant breeders' rights, brands, and quality signs are legal instruments whose power is underestimated and whose legitimacy is rarely questioned as though it were obvious. In fact, not everything should be eligible for ownership, particularly when goods are necessary for people to live. In this case, it should be forbidden on principle for an owner, whoever he or she might be, to have a power of monopoly on goods which people depend on for their very lives. But intellectual property is like any other property: it can be absolute or relative. International law currently provides few limits to intellectual property's absolute scope. States can rule out an invention's patentability so as to protect public order, health, and animals or people's lives or to avoid serious environmental problems ${ }^{\mathrm{n}}$. They can more generally rule out patentability for plants, animals, and their breeding processes, providing they organize an alternative way to protect plant varieties ${ }^{\circ}$. Exceptions in the International Convention for the Protection of New Varieties of Plants (UPOV) also limit the breeder's rights [38]. Besides, the Convention on Biological Diversity provides for the fair, equitable sharing of benefits from the use of genetic resources [39].

Yet all these limits, exceptions and expectations which could set limits to the 'inventor's' monopoly remain ineffective or too vague to have a full, legal reach, or can be neutralized in contracts between the owners of these monopolies and farmers. There is thus considerable progress to be made in deciding what should be 'common goods' as well as in regulating the powers and rights of the 'owner' of the variety or characteristics of the new animal or plant.

The intellectual property resource is all the more promising as it enables us to imagine an analogical transposition of the so-called right of cultural exception to the issue of food. Cultural exception is an international legal concept aimed at making culture an exception in international treaties and particularly in the World Trade Organization. This exception thus allows States the means to make their sovereignty prevail and to limit free trade in cultural products to the benefit of their national culture and cultural diversity. A food exception based on the same model is not impossible to imagine.

To conclude, regarding the food issues of trade in the land and what it holds, we have to go back to Hot Springs and supply law that would enable the implementation of the values that this quickly forgotten conference sought to enforce. If we do not, we cannot be sure that populations will accept for much longer that 'what has a price' triumphs over 'what has dignity'. Better Hot Springs than spring riots.

\section{Endnotes}

${ }^{\mathrm{a}}$ See the second section in Groundwork of the Metaphysics of Morals.

${ }^{\mathrm{b}} \mathrm{So}$ far Delmas-Marty $\mathrm{M}$ has devoted her Collège de France lectures to this subject and has published four volumes in the Seuil publishings (Paris): Le relatif et l'universel (t. 1), Le pluralisme ordonné (t. 2), La refondation des pouvoirs (t. 3), Vers une communauté de valeurs (t. 4).

${ }^{\mathrm{c}} \mathrm{See}$ particularly the first Poor Law (1601) and the Speenhamland law. The latter, in force from 1795 to 1834, set a minimum income depending on the number of dependent people and the price of bread. It was granted to those without an income and those with an income below the minimum one were granted the difference. It was abrogated in 1834 because it encouraged the textile industry to underpay its employees. Polanyi K, chap. 7, p. 128; Rodriguez J, "De la charité publique à la mise au travail. Autour du Speenhamland Act", http:// www.laviedesidees.fr/IMG/pdf/20080923_rodriguez.pdf 
${ }^{\mathrm{d}}$ Reasoned, more productive exploitation of land, sheep breeding, and textile industry development.

${ }^{\mathrm{e}}$ Many demonstrations, even riots took place in late 2007 to early 2008 in Africa (Burkina Faso, Cameroon, Senegal, Mauritania, Ivory Coast, Egypt, Morocco) but also in Mexico, Bolivia, Yemen, and in Bangladesh, Pakistan, Sri Lanka, and South Africa.

${ }^{\mathrm{f}}$ Let us remember the Doha Round is a negotiations cycle launched in 2001 under WTO's authority. These negotiations deal with agricultural products international trade and the improvement of the conditions for developing countries agricultural products to reach wealthy countries.

${ }^{g}$ One may however observe that in spite of a selfregulating economic pattern, only capitals and goods can circulate without restrictions. The situation is quite different for people.

${ }^{\mathrm{h}}$ See Geneva debate (11 May 2009) between Pascal Lamy, WTO's general director, and Olivier de Schutter, UNO's special rapporteur on food law.

${ }^{\mathrm{i}}$ See infra.

${ }^{\mathrm{j}}$ Especially the European Court for Human Rights, Supreme Courts in the USA and Canada, inter-American Court of Human rights.

${ }^{\mathrm{k}}$ Eod. loc.

${ }^{\mathrm{l}}$ See Ostrom, E., op. préc.

${ }^{m}$ See art. 27.2 of WTO's agreement on the aspects of intellectual properties dealing with trade (TRIPS).

${ }^{\mathrm{n}}$ See art. 27.3-b of TRIPS/WTO agreement.

${ }^{\circ}$ See art. 27.3-b of TRIPS/WTO agreement.

\section{Author's information}

Professor at the University of Nantes, Member of the Institut Universitaire de France, Principal investigator of Lascaux (www.droit-aliments-terre.eu). The Lascaux program (2009-2014) is linked to the 7th Framework Programme of the European Research Council ('IDEAS'). The research leading to these results has received funding from the European Research Council under the European Union's Seventh Framework Programme (FP7/2007-2013)/ERC grant agreement no. 230400

Received: 23 December 2011 Accepted: 23 April 2012 Published: 24 May 2012

\section{References}

1. World Trade Organization: Report on 2010 World Trade. Geneva: WTO; 2010.

2. Collart Dutilleul F, Garcia F: Dans le domaine de l'alimentation, quels "droits à" dans le "droit de"? In In Droit économique et Droits de l'Homme. Edited by Boy L, Racine J-B, Siiriainen F. Brussels: Larcier; 2009.

3. Hersch J: Les droits de l'homme d'un point de vue philosophique. In In La philosophie en Europe. Edited by Klibansky R, Pears D. Paris: Folio essais; 1993. 4. [http://www.droit-aliments-terre.eu]

5. Malamoud C, Angeno M, Dumont L: Aux origines politiques et économiques de notre temps, trad. Paris: Editions Gallimard; 2009.

6. PUF: coll. Paris: Epithémée; 2010.

7. Polanyi K: chap.1.38.

8. Tooze R: "Susan Strange et l'économie politique internationale", L'Économie politique, 2001/2 n 10, p.101. Also Cox, R. W., "Au-delà de l'empire de la terreur: réflexions sur l'économie politique de l'ordre mondial". Vol 2nd edition. H: A contrario; 2004:http://www.cairn.info/revue-a-contrario-2004-2-page-167.htm.
9. Foucault M: I'économie politique et le libéralisme, Annales Histoire, Sciences sociales. In In Naissance de la biopolitique, Cours au Collège de France, 1978-1979, Jan. 10, 1979 lecture. Edited by Ewald F, Fontana A, Senellart M, Grenier J-Y, Orléan A, Foucault M. Paris: Gallimard-Le Seuil; 2004:279-1155. Vol.62 (5/2007)

10. Polanyi K: 122 . chap.6.

11. Polanyi K: 118. loc. prec.

12. Neeson JM: Commoners: Common Right, Enclosure and Social Change in England 1700-1820. Cambridge: Cambridge University Press; 1993.

13. Chambers JD, Mingay GE: For lack of amicable agreement, enclosures had to be imposed by law, In The Agricultural Revolution 1750-1850. Batsford; 1982.

14. Gauthier F: De Mably à Robespierre: un programme économique égalitaire 1775-1793, In Annales historiques de la Révolution française, $n^{\circ} 261$, 1985.1792:265. available online: http://www.persee.fr/web/revues/home/ prescript/article/ahrf_0003-4436_1985_num_261_1_1116: Also see Robespierre's analysis, Opinion sur les subsistances, speech given at the Convention.

15. Clément A: La spécificité du fait alimentaire dans la théorie économique. Les fondements historiques et les enjeux. Ruralia 2000, Varia, [http://ruralia. revues.org/178]

16. Deblock C, Hamel B: Bretton Woods et l'ordre économique international d'après guerre", In Interventions économiques, Pour une alternative sociale. 1994/1995, n²6, Dossier spécial «De l'ordre des nations à l'ordre des marchés - Bretton Woods, cinquante ans plus tard »,12 [http://classiques. uqac.ca/contemporains/deblock_christian/bretton_woods_ordre_econo/ Bretton_Woods_ordre_eco.pdf]

17. Supiot $\bar{A}$ : L'esprit de Philadelphie: la justice sociale face au marché total. Paris: Seuil; 2010.

18. Hayek F: Droit, législation et liberté, t.1, Règles et ordres, chap.2, PUF. Paris: Quadrige; 2007.

19. Bernard A: Le marché autorégulé, "une idée folle"? Paris: Rec. Dalloz; 2009.

20. World Trade Organization: WTO Report on 2010 World Trade, Natural Resources Trade, part II, section E. Geneva: WTO; 2010.

21. Le commerce international entre bi et multilatéralisme: In Edited by Remiche B, Ruiz-Fabri H. avril: RIDE; 2010.

22. [http://www.fao.org/cfs/fr]

23. Collart Dutilleul F: La régulation juridique du développement durable et le droit agroalimentaire européen. In In Production et consommation durables: de la gouvernance au consommateur-citoyen, CEDE International Talks Acts. Edited by Parent G. Québec: Yvon Blais; 2008:393.

24. Coutu M: Max Weber et les rationalités du droit. LGDJ 1995, :123.

25. UNO's general assembly first debate on 'harmony with nature'. [http://www.un. org/News/frpress/docs/2011/AG11075.doc.htm]

26. Delmas-Marty M: Les forces imaginantes du droit, t.1, Le relatif et l'universel. Paris: Seuil; 2004.

27. La réforme du droit des contrats: projet et perspectives. Rev des Contrats (RDC) 2006, :22

28. Acts of Lascaux programme talks. 2010 [http://www.droit-aliments-terre.eu/ pages/menu2/forum_lascaux_2.html]

29. FAO draft report on Directives volontaires sur la gouvernance responsable de la tenure des terres et des autres ressources naturelles. 2012 [http://www.fao.org/ $\mathrm{nr} /$ tenure/voluntary-guidelines/e-consultation/fr/]

30. Collart Dutilleul F: Quel regard sur le phénomène de l'accaparement des terres? [http://www.droit-aliments-terre.eu/documents/sources_lascaux/editos/ edito_FCD/edito_062011_FR.pdf]

31. On this concept presented in 1996 in FAO's world summit on food in Rome. Bamako (Mali); 2007. see http://www.viacampesina.org/. See Nyeleni's statement in the international meeting on food security: http://www. nyeleni.org/.

32. Ostrom E: Gouvernance des biens communs - Pour une nouvelle approche des ressources naturelles. In In Révision scient. Edited by Baechler L.: de Boeck; 2010.

33. The tragedy of the Commons. Science 1968, 162:1243.

34. Coban A: Entre les droits de souveraineté des États et les droits de propriété: la régulation de la biodiversité, A contrario 2004/2, Vol. 2. 2004:138 [http://www. cairn.info/resume.php?ID_ARTICLE=ACO_022_0138]

35. See Robespierre's speech: Propositions d'articles additionnels à la déclaration des Droits de l'Homme et du citoyen. 1793.

36. Duguit L: Le droit social, le droit individuel et la transformation de l'État, conférences faites à l'École des Hautes Études Sociales. In In La Mémoire 
du Droit: Les transformations générales du droit privé depuis le code Napoléon. 2nd edition. Edited by Alcan P. 1999:147.

37. Commission on Intellectual Property Rights: Intégrer les droits de propriété intellectuelle et la politique de développement. London: CIPR; 2002 [http:// www.iprcommission.org/]

38. [http://www.upov.int/fr/about/upov_convention.htm]

39. [http://www.cbd.int/]

doi:10.1186/2048-7010-1-6

Cite this article as: Collart Dutilleul: The law pertaining to food issues

and natural resources exploitation and trade. Agriculture and Food Security 2012 1:6.

Submit your next manuscript to BioMed Central and take full advantage of:

- Convenient online submission

- Thorough peer review

- No space constraints or color figure charges

- Immediate publication on acceptance

- Inclusion in PubMed, CAS, Scopus and Google Scholar

- Research which is freely available for redistribution 